\title{
Stomatal and non-stomatal limitations to photosynthesis of Populus euphratica Oliv. leaves in an extremely arid area of northwestern China
}

Guanlong Gao ( $\square$ guanlong_gao@163.com )

https://orcid.org/0000-0003-3277-4126

Qi Feng

Northwest Institute of Eco-Environment and Resources

Xiande Liu

Academy of Water Resources Conservation Firests in Qilian Mountains of Gansu Province

Research article

Keywords: Photosynthesis; Stomatal limitation; Drought; Water stress; Populus euphratica

Posted Date: August 29th, 2019

DOl: https://doi.org/10.21203/rs.2.10987/v1

License: (c) (i) This work is licensed under a Creative Commons Attribution 4.0 International License.

Read Full License 


\section{Abstract}

On the basis of successive measurements of leaf gas exchange during the main growing seasons of Populus euphratica Oliv. in 2013 and 2014, respectively, we analyzed the stomatal and non-stomatal limitations to photosynthesis under natural conditions in an extremely arid region of northwestern China. Our results showed that (1) the distribution patterns of net photosynthesis $(\mathrm{Pn})$ and stomatal conductance (gs) were similar, both of which increased in the morning, peaked at around noon, and then decreased. This contrasted with the observed changes in sub-stomatal $\mathrm{CO} 2$ concentrations (Ci). (2) The phenomenon of midday depression of photosynthesis (MDP) was obvious from July to September during the two years. At the beginning of MDP, the stomatal limitation to photosynthesis (Ls) peaked, where its predominance was supported by $\mathrm{Ci}$ being at a minimum. Thereafter, Ls decreased and $\mathrm{Ci} / \mathrm{gs}$ increased sharply, indicating that the non-stomatal limitation to photosynthesis predominated. (3) Both the Ls and relative stomatal limitation to photosynthesis (RLs) increased in the morning, and then decreased, whereas $\mathrm{Ci} /$ gs presented contrary changes. (4) The RLs values were greater than the Ls values, which was mainly due to the nonlinearity of the $\mathrm{Pn} / \mathrm{Ci}$ curve, which often leads to large overestimations. (5) The Ls values in our study were much greater than those from other studies under natural conditions. The most probable reason was that the extremely high temperature and scarce water resource caused the stomata to close to reduce transpiration, resulting in the stomatal limitation to photosynthesis being more intense.

\section{Background}

Arid and semi-arid lands cover approximately $40 \%$ of Earth's terrestrial surface and are expanding globally (Reynolds 2000) and the arid regions are expected to become drier as a result of climate change (Dai 2011, Sheffield et al. 2012, McDowell et al. 2015). The ecosystems in arid and semi-arid lands represent a dynamic but poorly understood component of the global carbon, water, and energy cycles (Naithani et al. 2012). The Ejin oasis, which is located in the lower reaches of the Heihe River Basin of northwestern China, is one of the most arid regions in the world, with annual rainfalls of less than $50 \mathrm{~mm}$ (Si et al. 2009). Populus euphratica Oliv. is the constructive species of the desert riparian forest in this region, where its regular growth is important for the formation of a natural barrier to support the existence of the Ejin oasis. Owing to the lack of water resources, however, the $P$. euphratica forests have degenerated in this region in the last century.

Drought stress is an important environmental factor inhibiting the growth and reducing the yield of plants worldwide (Li et al. 2000, Li and Wang 2003, Zhang et al. 2005). The limitation of plant growth due to low water availability is mainly caused by reductions in the plant carbon balance, which is largely dependent on photosynthesis (Flexas et al. 2009). Photosynthesis, the basic manufacturing process required for the existence of life on this planet, contributes to more than $90 \%$ of crop biomass (Makino 2011). It can increase the carbon gain of crops and, thus, improve their yield and quality (Xie et al. 2017). Previous studies have shown that photosynthesis is one of the first physiological processes to be affected under drought (Lawlor 1995, Munns 2002). According to Farquhar and Sharkey (1982), there are two aspects to 
the restrictions in photosynthesis: (1) the intercellular $\mathrm{CO}_{2}$ concentration $\left(C_{i}\right)$ cannot meet the needs of photosynthesis owing to the limitation of stomatal conductance (stomatal limitation); and (2) the chloroplast and Rubisco activities and ribulose bisphosphate (RuBP) regeneration are decreased (nonstomatal limitation). Thus far, it is still unclear and under debate on whether drought limits photosynthesis mainly through stomatal or non-stomatal limitations (Noormets et al. 2001, Flexas and Medrano 2002).

Previous studies on stomatal and non-stomatal limitations of photosynthesis were conducted mostly under various controlled conditions, such as water stress (Ni and Pallardy 1992, Signarbieux and Feller 2011, Varone et al. 2012, Campos et al. 2014, Anev et al. 2016), saline-alkali stress (Steduto et al. 2000, Centritto et al. 2003, Meloni et al. 2003, Yang et al. 2008, Li et al. 2010), multifactor stress (Correia et al. 2005), and other stressors (Pereira et al. 2013, Maggard et al. 2016), whereas studies conducted under natural conditions were rare. In particular, in the extremely arid regions of northwestern China where the natural environments are harsh, studies on stomatal and non-stomatal limitations to photosynthesis have seldom been carried out. For $P$. euphratica grown in the Ejin oasis, researchers have focused mainly on the aspects of hydraulic redistribution (Yu et al. 2013), measuring and modeling of evapotranspiration and stomatal conductance (Hou et al. 2010, Zhu et al. 2011, Gao et al. 2016a, 2016b, 2017), and so on, whereas little research effort has been devoted to the stomatal and non-stomatal limitations to photosynthesis. Furthermore, drought can decrease the leaf photosynthetic rate (Zhou et al. 2015), which consequently limits the ecosystem productivity of $P$. euphratica. Therefore, the study of stomatal and non-stomatal limitations to photosynthesis of $P$. euphratica leaves in extremely arid areas is of particular importance.

The objectives of this study were to (1) analyze the diurnal changes in the environmental conditions and physiological factors of $P$. euphratica leaves and (2) study the stomatal and non-stomatal limitations to photosynthesis of $P$. euphratica leaves under natural conditions in an extremely arid region. Our research should be of great significance, as the analysis of stomatal and non-stomatal limitations to photosynthesis of $P$. euphratica leaves under natural conditions in the Ejin oasis has not yet been reported.

\section{Methods}

\subsection{Experimental site}

Measurements of leaf gas exchange in $P$. euphratica leaves were recorded at the Qidaoqiao $P$. euphratica Forest Reserve in Ejin County (Inner Mongolia, China) from June to September in 2013 and 2014, respectively (Fig. 1, $42^{\circ} 21^{\prime} \mathrm{N}, 101^{\circ} 15^{\prime} \mathrm{E}$, altitude $920.5 \mathrm{~m}$ a.s.I.). In the forest reserve, the average tree age is 32 years, with good growth status. The trees have an average height of $10.2 \mathrm{~m}$, an average diameter at breast height of $24.67 \mathrm{~cm}$, and an average crown breadth of $442 \mathrm{~cm}{ }^{\prime} 450 \mathrm{~cm}$. The soil is sandy loam of approximately $2 \mathrm{~m}$ in depth and has a volumetric water content of $0.35 \mathrm{~m}^{3} \mathrm{~m}^{-3}$. The bulk density of the soil is $1.53 \mathrm{~g} \mathrm{~cm}^{-3}$. 


\subsection{Measurements and data processing}

We selected three individual $P$. euphratica trees in 2013 and 2014, respectively, and measured the leaf gas exchange in three fully expanded leaves of each tree hourly from the east and west, on four or five sunny days every month. An LI-6400 portable photosynthesis system (LI-COR Inc., Lincoln, NE, USA) was used for the measurements. We measured all the available parameters; namely, net photosynthesis $\left(P_{n}, \mu \mathrm{mol} \mathrm{CO} \mathrm{m}^{-2} \mathrm{~s}^{-1}\right)$, stomatal conductance $\left(g_{s}, \mathrm{~mol} \mathrm{H}_{2} \mathrm{O} \mathrm{m}^{-2} \mathrm{~s}^{-1}\right)$, sub-stomatal and ambient $\mathrm{CO}_{2}$ concentrations $\left(C_{i}\right.$ and $C_{a}, \mu \mathrm{mol} \mathrm{CO} \mathrm{Col}^{-1}$ ), photosynthetically active radiation (PAR, $\mu \mathrm{mol} \mathrm{m} \mathrm{m}^{-2} \mathrm{~s}^{-1}$ ), air temperature $\left(T_{a},{ }^{\circ} \mathrm{C}\right)$, relative humidity $\left(h_{s} \%\right)$, and vapor pressure deficit (VPD, $\left.\mathrm{kPa}\right)$. The measurements were conducted from 8:00 to 20:00, where the observation session was adjusted by advancing or postponing it by $1 \mathrm{~h}$ according to the specific circumstances of sunrise and sunset. We also used a sky lift to reach the canopy when measuring the leaves. The sample sizes in 2013 and 2014 were 103 averages based on 927 measurements and 183 averages based on 1647 measurements, respectively.

\subsection{Formulae}

Stomatal limitation to photosynthesis can be quantified by the parameter $L_{s}$ which can be calculated according to the following formula described by Farquhar and Sharkey (1982):

Due to technical limitations, Equation 1 has been placed in the Supplementary Files section.

where $G$ is the $\mathrm{CO}_{2}$ compensation point of assimilation in the presence of dark respiration. $G$ can always be neglected, whereupon the formula is then expressed as follows:

Due to technical limitations, Equation 2 has been placed in the Supplementary Files section.

Another way to quantify the relative importance of the stomata in controlling the processes of photosynthesis is the resistance-based method described by Jones (Jones 1998), who proposed the relative stomatal limitation to photosynthesis $\left(R L_{s}\right)$. The value can be calculated by the following formula:

Due to technical limitations, Equation 3 has been placed in the Supplementary Files section. 
where $r_{s}$ is the stomatal resistance, $r_{a}$ is the boundary layer resistance, and $r^{*}$ is the slope of the tangent to the $P_{n} / C_{i}$ curve at the operating point.

$r_{s}$ and $r_{a}$ can be calculated by the following formulae:

Due to technical limitations, Equation 4 has been placed in the Supplementary Files section.

where $I_{w}$ is the leaf width, $u_{h}$ is the wind speed at the top of the canopy, and $h$ is the mean height of the canopy.

The non-stomatal limitation to photosynthesis can be indicated by $C_{i} / g_{s}$.

\section{Discussion}

\subsection{Diurnal changes in the environmental factors}

Detailed information on the key environmental variables is essential to assess diurnal changes in the stomatal and non-stomatal limitations to photosynthesis. We chose one sunny day per month to analyze the diurnal change patterns of the environmental factors (PAR, $T_{a}, \mathrm{VPD}$, and $h_{s}$ ) during the main growing seasons of $P$. euphratica in 2013 and 2014, respectively (Fig. 2). Generally, the distribution patterns of PAR, $T_{a}$, and VPD all presented single-peak curves. For the most part, PAR, $T_{a}$, and VPD increased in the morning, peaked between 13:00 and 15:00, and then decreased. During the study period, the daily average PAR was $941.74 \mathrm{~W} \mathrm{~m}^{-2}$, varying from 11.62 to $1689.33 \mathrm{~W} \mathrm{~m}^{-2}$. The daily average $T_{a}$ was $31.60^{\circ} \mathrm{C}$, which was very close to those of the previous years (data not shown). The $h_{s}$ value decreased gradually after 10:00, mainly due to the increase in $T_{a}$, which in turn caused the enhancement of evaporation and water loss to the air. The daily average $h_{s}$ was $46.63 \%$, varying from $17.54 \%$ to 75.21 $\%$. It was obvious that the values for all four parameters did not show significant differences between 2013 and 2014.

\subsection{Diurnal changes in the physiological factors}

We selected the same days to analyze the diurnal change patterns of the physiological factors $\left(P_{n}, g_{S}\right.$ and $C_{i}$ ) during the main growing seasons of $P$. euphratica in 2013 and 2014, respectively (Fig. 3). We can see from Figure 3 that the distribution patterns of $P_{n}$ and $g_{s}$ were similar. $P_{n}$ increased in the morning, peaked at around 14:00, and then decreased. In August and September, the values of $P_{n}$ were much greater than those in June and July. The $g_{s}$ value increased rapidly in the morning, peaked between 10:00 and 12:00, and then decreased gradually in the afternoon. The peak values of $g_{s}$ in the different months 
were fairly close to one another $\left(0.40-0.46 \mathrm{~mol} \mathrm{H}_{2} \mathrm{O} \mathrm{m}^{-2} \mathrm{~s}^{-1}\right)$. We can also see that there were fluctuations in $P_{n}$ and $g_{s}$ between 11:00 and 14:00 from July to September, which indicated the obvious phenomenon of midday depression of photosynthesis (MDP) (e.g., July and September 2013 and August 2014, respectively). $C_{i}$ presented a contrasting pattern of diurnal changes to those of $P_{n}$ and $g_{s}$ (Fig. 3), where the minimums appeared between 14:00 and 16:00. The ranges of $g_{s}$ and $C_{i}$ values in the different months were similar, where $g_{s}$ ranged from 0.02 to $0.47 \mathrm{~mol} \mathrm{H}_{2} \mathrm{O} \mathrm{m}^{-2} \mathrm{~s}^{-1}$ and $C_{i}$ ranged from 126.78 to $401.21 \mu \mathrm{mol} \mathrm{CO} \mathrm{mol}^{-1}$.

\subsection{Diurnal changes in $L_{s} R L_{s}$ and $C_{i} / g_{s}$}

The diurnal changes in $L_{S}, R L_{S}$ and $C_{j} / g_{s}$ during the main growing seasons of $P$. euphratica in 2013 and 2014 are shown in Figure 4. We can see that both $L_{s}$ and $R L_{s}$ increased in the morning and then decreased. The $L_{s}$ values in the afternoon were significantly greater than those in the morning. Generally, the $R L_{s}$ values were greater than the $L_{s}$ values. $C_{j} / g_{s}$ presented a contrasting pattern of diurnal changes to those of $L_{s}$ and $R L_{s}$. The $C_{i} / g_{s}$ values were generally low in the morning and increased sharply after 17:00. The highest values of these parameters in 2013 and 2014 were 0.51 and 0.70 for $L_{s}, 0.44$ and 0.58 for $R L_{s}$ and 7.30 and 4.83 for $C_{j} / g_{s}$, respectively.

\section{Conclusions}

The Ejin oasis is one of the most arid regions in the world, and less precipitation can be expected to be available for plants there. Drought can be considered as one of the main environmental factors limiting photosynthesis and plant productivity. Nevertheless, whether water deficit affects plant photosynthesis via stomatal or non-stomatal limitation is still unclear and under debate. In order to clarify this question, we analyzed stomatal and non-stomatal limitations to photosynthesis under natural conditions in an extremely arid region of northwestern China through successive measurements of leaf gas exchange in $P$. euphratica during its main growing seasons in 2013 and 2014, respectively.

The diurnal changes in $C_{i}$ presented "V-shaped" curves (greater $C_{i}$ values in the morning and evening, and lower values at noon), which was basically consistent with the conclusions made in studies of Wheat (Jiang et al. 2001) and Haloxylon ammodendron (Yang et al. 2015) in arid regions. The similarity in the distribution patterns of $P_{n}$ and $g_{s}$ indicated that $g_{s}$ was to some extent the main factor influencing $P_{n}$ under extremely arid conditions.

During the study periods, especially from July to September, the MDP phenomenon was evident. This was mainly owing to the high transpiration rates caused by the high VPD values, which led to an intense water deficit in the leaves. On the one hand, $g_{s}$ decreased and limited the entry of $C_{a}$; on the other hand, the water deficit caused a decrease in mesophyll conductance $\left(g_{m}\right)$, which decreased the $\mathrm{CO}_{2}$ concentration in the chloroplast to a very low level, resulting in the decrease in $P_{n}$. For $P$. euphratica 
growing in extremely arid regions from July to September, where the $T_{a}$ at around noon is the highest and the transpiration rate is the fastest, MDP can protect the tree from losing too much water.

Although the $L_{s}$ increased gradually in the morning and then decreased, it still remained at high levels and was the main reason for the decrease in $P_{n}$ in the afternoon. During the MDP periods, $L_{s}$ peaked, and $C_{i}$ was at a minimum, showing the apparent stomatal limitation to photosynthesis. This was consistent with the viewpoint of Farquhar and Sharkey (1982), who proposed the simultaneous increase in $L_{s}$ and decrease in $C_{i}$ as being the criterion for determining stomatal limitation. The low soil moisture content limited the water uptake by $P$. euphratica, and the intense solar radiation and high VPD values increased the water loss from the trees. Owing to a combination of transpiration and photosynthesis, the stomata closed to maintain water balance inside the plant and limit $\mathrm{CO}_{2}$ entry into the leaves. Therefore, stomatal limitation to photosynthesis was predominant. Afterward, $L_{s}$ decreased and $C_{j} / g_{s}$ increased sharply, and the non-stomatal limitation to photosynthesis predominated. Several studies have shown $g_{m}$ to be the main factor controlling non-stomatal limitation to photosynthesis, especially under stress (Grassi and Magnani 2005, Niinemets et al. 2005, Warren 2008). The structure of leaves determined the maximum value of $g_{m}$ (Nobel 1977), and $g_{m}$ also changed rapidly according to the environment conditions (Flexas et al. 2008). In extremely arid regions (like our study area, Ejin oasis), the soil moisture content is very low, and water stress is the main factor limiting $g_{m}$ (Scartazza et al. 1998, Delfine et al. 2001, Monti et al. 2006). Because a greater VPD usually leads to lower $g_{m}$ (Bongi and Loreto, 1989), we can infer that the $g_{m}$ values in the morning were greater than those in the afternoon, as the VPD changed inversely (Fig. 2). It was much easier for $C_{i}$ to enter into the chloroplast through the cytomembrane and cytoplasm and supply the $\mathrm{CO}_{2}$ that would be consumed by photosynthesis, leading subsequently to low $C_{j} / g_{s}$ values in the morning. In the afternoon, $g_{m}$ decreased and hindered the diffusion of $\mathrm{CO}_{2}$ into the chloroplast, and $C_{i} / g_{s}$ subsequently increased.

We can also see from Figure 4 that the values of $R L_{s}$ were greater than those of $L_{s}$ and this was mainly due to the nonlinearity of the $P_{n} / C_{i}$ curve. Such occurrence often leads to a large overestimation of the importance of the stomata in controlling photosynthesis (Jones 1998). Consequently, $L_{s}$ is more applicable than $R L_{s}$ for representing stomatal limitation to photosynthesis. We have summarized the maximum $L_{s}$ values of different species from previous research studies and this study in Table 1 . We can see that the maximum $L_{s}$ values from Yang et al. (2015) (0.64) and this study (0.70 in 2013 and 0.51 in 2014, respectively) were much greater than those from other studies, probably because both experiments were conducted under conditions of extremely intense water stress in northwestern China. At our study site specifically, $P$. euphratica grew in an environment with high temperatures (mean $T_{a}$ values at $31.6^{\circ} \mathrm{C}$ in 2013 and $29.9^{\circ} \mathrm{C}$ in 2014, respectively) and scarce water resources (annual precipitation of $25.6 \mathrm{~mm}$ and $27.0 \mathrm{~mm}$, and mean $h_{s}$ values of $54.2 \%$ and $43.0 \%$ in 2013 and 2014, respectively) during the study periods, and therefore, the stomata closed to reduce transpiration, resulting in the predominance of stomatal limitation to photosynthesis. 
As our data were obtained using the LI-6400 portable photosynthesis system, there was a lack of parameters (chloroplast structure, photosynthetic pigment content, Rubisco activity, RuBP regeneration capacity) measured to represent the non-stomatal limitation to photosynthesis. We will make up for this in our future work.

\section{Declarations}

\section{Acknowledgements}

We would like to thank Qi Feng for his careful reading and helpful comments on this manuscript. We extend our thanks to the reviewers and editors for their careful reading and helpful comments on this manuscript.

\section{Authors' contributions}

X.L. and Q.F. designed and G.G. performed the experiments; all authors analyzed the data; G.G. wrote the manuscript; Q.F. provided the guidance on the whole manuscript and all authors read and approved the final manuscript.

\section{Funding}

This study was supported by the Chinese Post-doctoral Science Foundation (2018M643769), Shanxi Province Science Foundation for Youths (201801D221286), Fund Project of Shaanxi Key Laboratory of Land Consolidation (2018-JC13), and the Fundamental Research Funds for the Central Universities, CHD (300102279505). We gratefully acknowledge the valuable comments from anonymous reviewers on an earlier version of our manuscript.

\section{Availability of data and materials}

All data generated or analyzed during this study are included in this published article.

\section{Ethics approval and consent to participate}

Not applicable. 


\section{Consent for publication}

Not applicable.

\section{Competing interests}

The authors have no conflict of interest to declare.

\section{References}

Anev S, Marinova A, Tzvetkova NP, Panayotov MP, Yurukov S (2016) Stomatal control on photosynthesis in drought-treated subalpine pine saplings. Genet Plant Physiol 6: 43-53.

Bongi G, Loreto F (1989) Gas-Exchange Properties of Salt-Stressed Olive (Olea europea L.) Leaves. Plant Physiol 90: 1408-1416.

Campos H, Trejo C, Peña-Valdivia CB, Garcia-Nava R, Conde-Martínez FV, Cruz-Ortega MR (2014) Stomatal and non-stomatal limitations of bell pepper (capsicum annuum L.) plants under water stress and re-watering: Delayed restoration of photosynthesis during recovery. Environ Exp Bot 98: 56-64.

Centritto M, Loreto F, Chartzoulakis K (2003) The use of low $\left[\mathrm{CO}_{2}\right]$ to estimate diffusional and nondiffusional limitations of photosynthetic capacity of salt-stressed olive saplings. Plant Cell Environ 26: 585-594.

Correia CM, Pereira JMM, Coutinho JF, Björn LO, Torres-Pereira JMG (2005) Ultraviolet-B radiation and nitrogen affect the photosynthesis of maize: a Mediterranean field study. Eur J Agron 22: 337-347.

Dai A (2011) Drought under global warming: a review, Clim Change. 2: 45-65.

Delfine S, Loreto F, Alvino A (2001) Drought-stress effects on physiology, growth and biomass production of rainfed and irrigated bell pepper plants in the Mediterranean region. J Am Soc Hortic Sci 126: 297304.

Farquhar GD, Sharkey TD (1982) Stomatal conductance and photosynthesis. Annu Rev Plant Physiol 33: 317-345.

Flexas J, Medrano H (2002) Drought-inhibition of photosynthesis in C3 plants: stomatal and nonstomatal limitations revisited. Ann Bot 89: 183-189.

Flexas J, Ribas-Carbó M, Diaz-Espejo A, Galmés J, Medrano H (2008) Mesophyll conductance to $\mathrm{CO}_{2}$ : Current knowledge and future prospects. Plant Cell Environ 31: 602-621. 
Flexas J, Barón M, Bota J, Ducruet JM, Gallé A, Galmés J, Jiménez M, Pou A, Ribas-Carbó M, Sajnani C, Tomàs M, Medrano H (2009) Photosynthesis limitations during water stress acclimation and recovery in the drought-adapted Vitis hybrid Richter-110 (V. berlandierix V. rupestris). J Exp Bot 60: 2361-2377.

Gao GL, Zhang XY, Yu TF (2016) Evapotranspiration of Populus euphratica Oliv. forest during the growing season in the extreme arid region northwest China using Shuttleworth-Wallace model. J Forestry Res 27: 879-887.

Gao GL, Zhang XY, Yu TF (2017) Comparison of leaf stomatal conductance models for typical desert riparian phreatophytes in northwestern China. Agroforest Syst 91: 927-939.

Gao GL, Zhang XY, Yu TF, Liu B (2016) Comparison of three evapotranspiration models with eddy covariance measurements for a Populus euphratica Oliv. forest in an arid region of northwestern China. $J$ Arid Land 8: 146-156.

Grassi G, Magnani F (2005) Stomatal, mesophyll conductance and biochemical limitations to photosynthesis as affected by drought and leaf ontogeny in ash and oak trees. Plant Cell Environ 28: 834-849.

Hou LG, Xiao HL, Si JH, Xiao SC, Zhou MX, Yang YG (2010) Evapotranspiration and crop coefficient of Populus euphratica olive forest during the growing season in the extreme arid region northwest China. Agric Water Manage 97: 351-356.

Jiang TR, Zhang LX, Bi YR, Jia XH, Feng JC, Tao L, Liu XM (2001) Effects of water stress on gas exchange characteristics of haloxylon ammodendron leafs. Journal of Lanzhou University: Natural Science 37: 57-62. (in Chinese)

Jones HG (1998) Stomatal control of photosynthesis and transpiration. J Exp Bot 49: 387-398.

Lawlor DW (1995) The effects of water deficit on photosynthesis. In: Smirnoff, N. (Ed.), Environment and Plant Metabolism-Flexibility and Acclimation. BIOS Scientific Publisher, Oxford, pp 129-160.

Li CY, Berninger F, Koskela J, Sonninen E (2000) Drought responses of Eucalyptus microtheca provenances depend on seasonality of rainfall in their place of origin. Aust J Plant Physiol 27: 231-238.

Li CY, Wang KY (2003) Differences in drought responses of three contrasting Eucalyptus microtheca F. Muell. Populations. Forest Ecol Manage 179: 377-385.

Li R, Shi F, Fukuda K, Yang YL (2010) Effects of salt and alkali stresses on germination, growth, photosynthesis and ion accumulation in alfalfa (Medicago sativa L.). Soil Sci Plant Nutr 56: 725-733.

Maggard AO, Will RE, Wilson DS, Meek CR, Vogel JG (2016) Fertilization reduced stomatal conductance but not photosynthesis of Pinus taeda which compensated for lower water availability in regards to growth. Forest Ecol Manage 381: 37-47. 
Makino A (2011) Photosynthesis, grain yield, and nitrogen utilization in rice and wheat. Plant Physiol 155: 125-129.

McDowell NG, Coops NC, Beck PSA, Chambers JQ, Gangodagamage C, Hicke JA, Huang CY, Kennedy R, Krofcheck DJ, Litvak M, Meddens AJH, Muss J, Negrón-Juarez R, Peng CH, Schwantes AM, Swenson JJ, Vernon LJ, Williams AP, Xu CG, Zhao MS, Running SW, Allen CD (2015) Global satellite monitoring of climate induced vegetation disturbances. Trends Plant Sci 20: 114-123.

Meloni DA, Oliva MA, Martinez CA, José C (2003) Photosynthesis and activity of superoxide dismutase, peroxidase and glutathione reductase in cotton under salt stress. Environ Exp Bot 49: 69-76.

Monti A, Brugnoli E, Scartazza A, Amaducci MT (2006) The effect of transient and continuous drought on yield, photosynthesis and carbon isotope discrimination in sugar beet (Beta vulgaris L.). J Exp Bot 57: $1253-1262$.

Munns R (2002) Comparative physiology of salt and water stress. Plant Cell Environ 25: 239-250.

Naithani KJ, Ewers BE, Pendall E (2012) Sap flux-scaled transpiration and stomatal conductance response to soil and atmospheric drought in a semi-arid sagebrush ecosystem. J Hydrol 464-465: 176185.

Ni BR, Pallardy SG (1992) Stomatal and nonstomatal limitations to net photosynthesis in seedlings of woody angiosperms. Plant Physiol 99: 1502-1508.

Niinemets Ü, Cescatti A, Rodeghiero M, Tosens T (2005) Complex adjustments of photosynthetic potentials and internal diffusion conductance to current and previous light availabilities and leaf age in Mediterranean evergreen species Quercusilex. Plant Cell Environ 29: 1159-1178.

Noormets A, Sôber A, Pell EJ, Dickson RE, Podila GK, Sôber J, Isebrands JG, Karnosky DF (2001) Stomatal and non-stomatal limitation to photosynthesis in two trembling aspen (Populus tremuloides Michx.) clones exposed to elevated $\mathrm{CO}_{2}$ and/or $\mathrm{O}_{3}$. Plant Cell Environ 24: 327-336.

Nobel PS (1977) Internal leaf area and cellular $\mathrm{CO}_{2}$ resistance: Photosynthetic implications of variations with growth conditions and plant species. Physiol Plantarum 40: 137-144.

Pereira EG, Oliva MA, Rosado-Souza L, Mendes GC, Colares DS, Stopato CH, Almeida AM (2013) Iron excess affects rice photosynthesis through stomatal and non-stomatal limitations Plant Sci 201: 81-92.

Reynolds JF (2000) Desertification. In: Levin, S.A. (Ed.), Encyclopedia of Biodiversity. Academic Press, San Diego, pp 61-78.

Scartazza A, Lauteri M, Guido MC, Brugnoli E (1998) Carbon isotope discrimination in leaf and stem sugars, water-use efficiency and mesophyll conductance during different developmental stages in rice subjected to drought. Aust J Plant Physiol 25: 489-498. 
Sheffield J, Wood EF, Roderick ML (2012) Little change in global drought over the past 60 years. Nature 491: 435-438.

Si JH, Feng Q, Wen XH, Su YH, Xi HY, Chang ZQ (2009) Major ion chemistry of groundwater in the extreme arid region northwest China. Environ Geol 57: 1079-1087.

Signarbieux C, Feller U (2011) Non-stomatal limitations of photosynthesis in grassland species under artificial drought in the field. Environ Exp Bot 71: 192-197.

Steduto P, Albrizio R, Gionio P, Sorrentino G (2000) Gas-exchange response and stomatal and nonstomatal limitations to carbon assimilation of sunflower under salinity. Environ Exp Bot 75: 235-247.

Tissue DT, Griffin KL, Turnbull MH, Whitehead D (2005) Stomatal and non-stomatal limitations to photosynthesis in four tree species in a temperate rainforest dominated by Dacrydium cupressinum in New Zealand. Tree Physiol 25:447-456.

Varone L, Ribas-Carbo M, Cardona C, Gallé A, Medrano H, Gratani L, Flexas J (2012) Stomatal and nonstomatal limitations to photosynthesis in seedlings and saplings of Mediterranean species preconditioned and aged in nurseries: Different response to water stress. Environ Exp Bot 75: 235-247.

Warren CR (2008) Stand aside stomata, another actor deserves centre stage: The forgotten role of the internal conductance to $\mathrm{CO}_{2}$ transfer. J Exp Bot 59: 1475-1487.

Xie XL, Xia XJ, Kuang S, Zhang XL, Yin XR, Yu JQ, Chen KS (2017) A novel ethylene responsive factor CitERF13 plays a role in photosynthesis regulation. Plant Sci 256: 112-119.

Yang ZS, Zhang Q, Hao XC (2015) Stomatal or non-stomatal limitation of photosynthesis of spring wheat flag leaf at late growth stages under natural conditions in semiarid rainfed regions. Chin $\mathrm{J}$ Eco-Agric 23: 174-182. (in Chinese)

Yang CW, Jianaer A, Li CY, Shi DC, Wang DL (2008) Comparison of the effects of salt-stress and alkalistress on photosynthesis and energy storage of an alkali-resistant halophyte Chloris virgata. Photosynthetica 46: 273-278.

Yu TF, Feng Q, Si JH, Xi HY, Li ZX, Chen AF (2013) Hydraulic redistribution of soil water by roots of two desert riparian phreatophytes in northwest China's extremely arid region. Plant Soil 372: 297-308.

Zhang X, Wu N, Li C (2005) Physiological and growth responses of Populus davidiana ecotypes to different soil water contents. J Arid Environ 60: 567-579.

Zhou L, Wang SQ, Chi YG, Li QK, Huang K, Yu QZ (2015) Responses of photosynthetic parameters to drought in subtropical forest ecosystem of China. Sci Rep 5: 18254-18264. 
Zhu GF, Li X, Su YH, Lu L, Huang C (2011) Seasonal fluctuations and temperature dependence in photosynthetic parameters and stomatal conductance at the leaf scale of Populus euphratica Oliv. Tree Physiol 31: 178-195.

\section{Tables}

Table 1 Maximum values of stomatal limitation to photosynthesis $\left(L_{s}\right)$ under natural conditions for different species from previous research studies and this study

\begin{tabular}{|c|c|c|c|}
\hline Species & Maximum $L_{s}$ & Location & Literature resources \\
\hline Dacrydium cupressinum Lamb. & 0.29 & New Zealand & Tissue et al. (2005) \\
\hline \multicolumn{4}{|l|}{ Meterosideros umbellate Cav. } \\
\hline & 0.41 & & \\
\hline Weinmannia racemosa L.f. & 0.42 & & \\
\hline Quintinia acutifolia Kirk. & 0.41 & & \\
\hline Quercus robur $\mathrm{L}$. & 0.17 & Italy & Grassi and Magnani (2005) \\
\hline Fraxinus oxyphylla Bieb. & 0.21 & & \\
\hline Spring wheat & 0.64 & China & Yang et al. (2015) \\
\hline \multirow[t]{2}{*}{ Populus euphratica Oliv. } & $0.70(2013)$ & China & This study \\
\hline & $0.51(2014)$ & & \\
\hline
\end{tabular}




\section{Figures}

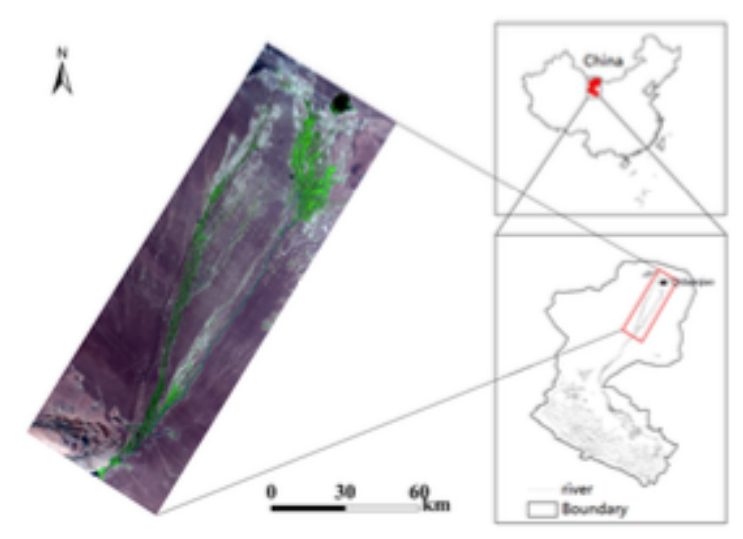

\section{Figure 1}

Location map of the study area. Note: The designations employed and the presentation of the material on this map do not imply the expression of any opinion whatsoever on the part of Research Square concerning the legal status of any country, territory, city or area or of its authorities, or concerning the delimitation of its frontiers or boundaries. This map has been provided by the authors. 

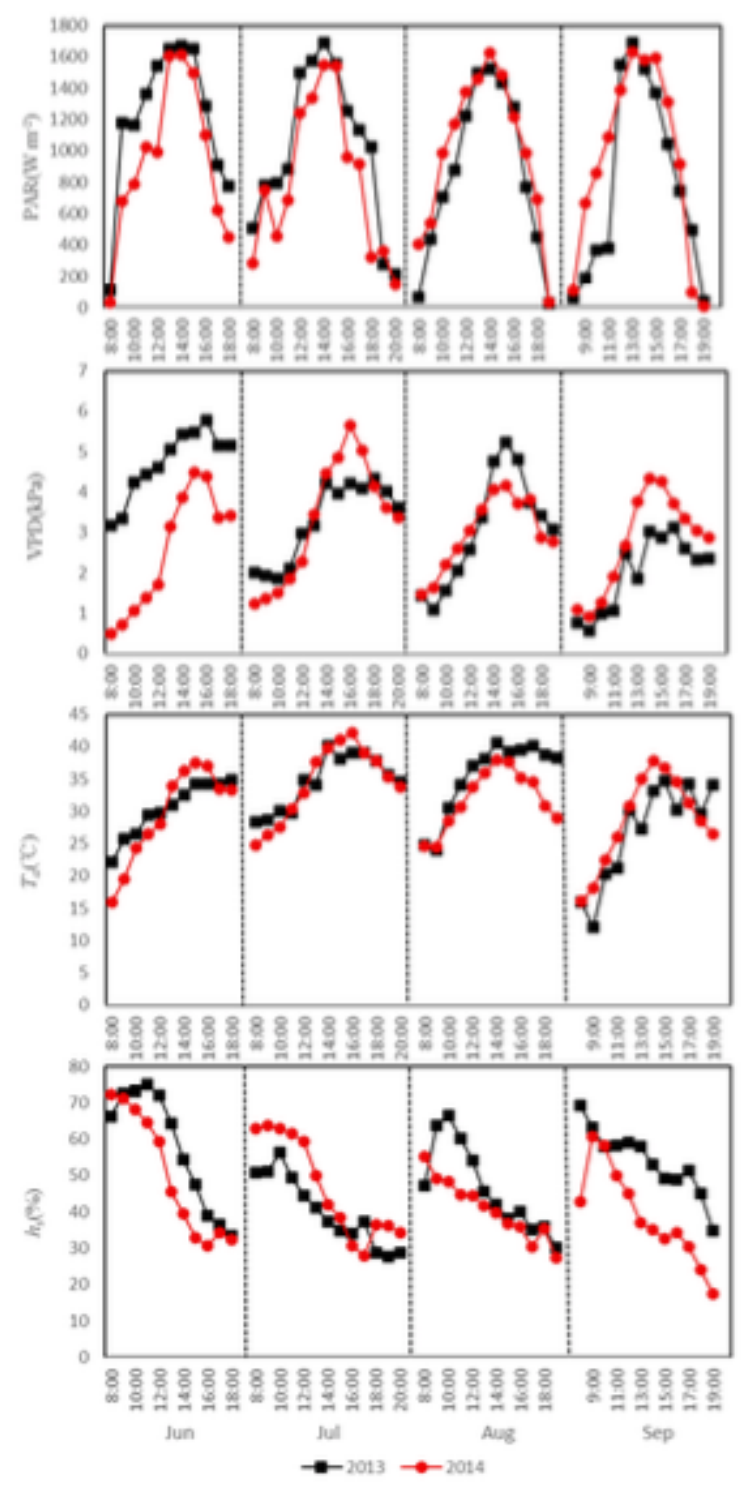

\section{Figure 2}

Diurnal change patterns of photosynthetically active radiation (PAR), vapor pressure deficit (VPD), air temperature $(\mathrm{Ta})$ and relative humidity (hs) during the main growing seasons of Populus euphratica in 2013 and 2014, respectively. 

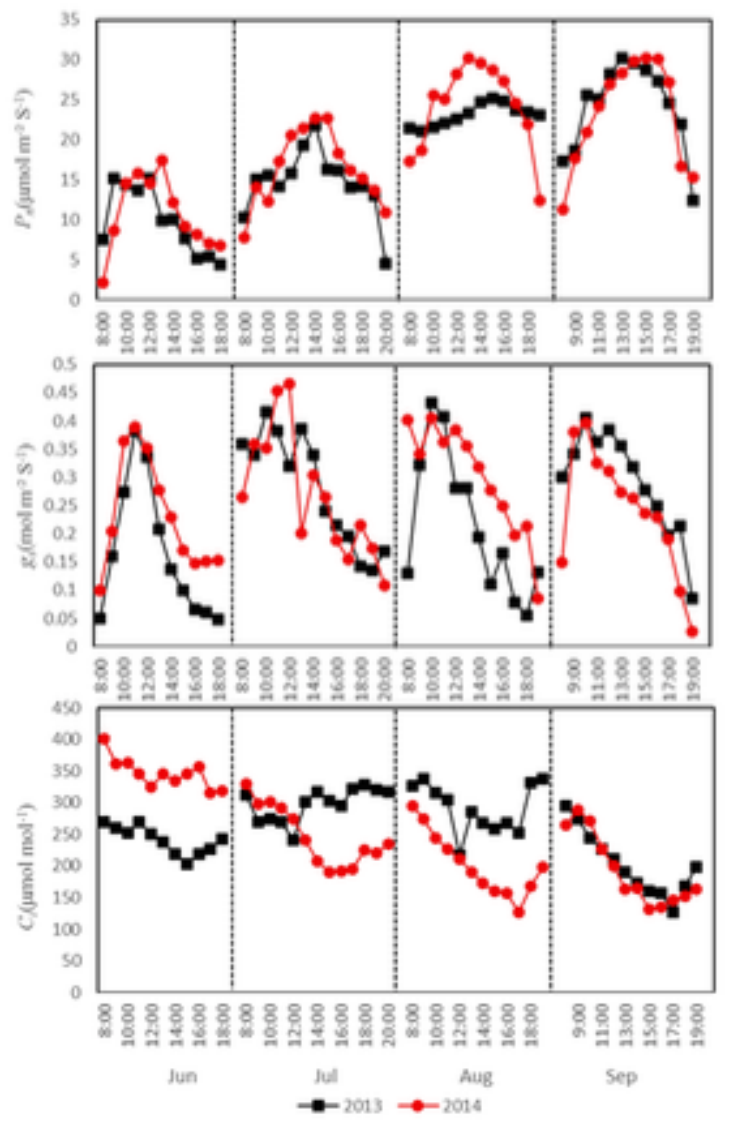

Figure 3

Diurnal change patterns of the net photosynthetic rate (Pn), stomatal conductance (gs), and intercellular CO2 concentration (Ci) during the main growing seasons of Populus euphratica in 2013 and 2014, respectively.

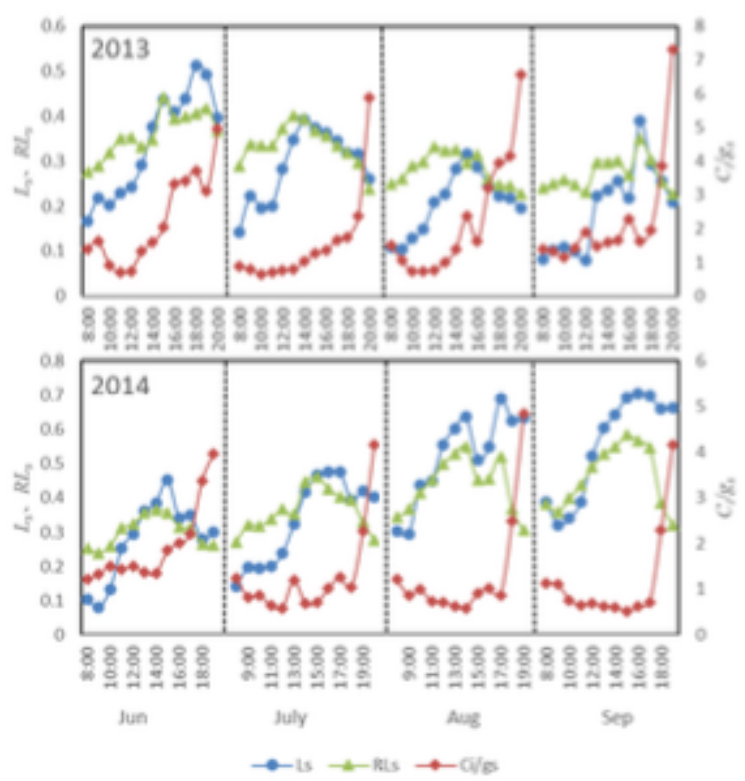




\section{Figure 4}

Diurnal change patterns of (relative) stomatal and non-stomatal limitations to photosynthesis of Populus euphratica leaves during the main growing seasons in 2013 and 2014, respectively. RLs, relative stomatal limitation to photosynthesis; Ls, stomatal limitation to photosynthesis; Ci/gs, non-stomatal limitation to photosynthesis.

\section{Supplementary Files}

This is a list of supplementary files associated with this preprint. Click to download.

- Equation4.png

- Equation3.png

- Equation1.png

- Equation2.png 